\title{
Mature teratoma of the spinal cord in adults: An unusual case
}

\author{
YUAN LI, BO YANG, LAIJUN SONG and DONGMING YAN
}

Department of Neurosurgery, The First Affiliated Hospital of Zhengzhou University, Zhengzhou, Henan 450052, P.R. China

Received January 4, 2013; Accepted May 14, 2013

DOI: $10.3892 / \mathrm{ol} .2013 .1519$

\begin{abstract}
Intraspinal mature teratomas rarely occur in adults. The present study describes an unusual case of adult intradural mature teratoma, which was completely resected. A 22-year-old female presented with an intermittent pinching pain in the lower right shank that had lasted for three months. Magnetic resonance imaging (MRI) results indicated a multicystic mass extending from the T12 to L2 vertebrae, and the tumors were certified as teratomas by a histopathological examination. The level of pain experienced by the patient was improved following the surgery. The present study also compared the literature concerning adult intradural mature teratoma, summarized the basic clinical characteristics and theory of origin of adult intradural mature teratoma and reviewed the available treatments for this disease.
\end{abstract}

\section{Introduction}

Teratomas are a type of multipotential cell tumor that contain a mixture of multiple germinal layers formed by normal organogenesis and reproductive tissues. Based on the degree of differentiation, teratomas may be classified as mature, immature or malignant (1). The incidence of spinal teratoma is rare; only $0.15-0.18 \%$ of spinal tumors have been classified as teratomas (2). In pediatric patients, $\sim 5-10 \%$ of spinal tumors are intraspinal teratomas (3-5), however, the incidence in adult patients is significantly lower than that observed in children and infants (6-12).

Unlike in intraspinal teratomas in infants and children, the symptoms of these tumors in adult patients typically lack specific clinical features that, upon diagnosis, may cause confusion with other spinal tumors, such as schwannomas, which are more commonly observed in adult patients (13). At present, the mechanism of intraspinal teratoma formation and the prognosis of the disease following surgery have not yet

Correspondence to: Dr Bo Yang, Department of Neurosurgery, First Affiliated Hospital of Zhengzhou University, 1 Jianshe Road, Zhengzhou, Henan 450052, P.R. China

E-mail: yangbo96@yahoo.com

Key words: intradural, intramedullary, spinal cord, teratoma, adult, case report been elucidated. Written informed consent was obtained from the patient.

\section{Case report}

A 22-year-old previously healthy female presented with an intermittent pinching pain in the lower right shank that had lasted for three months, progressive lower right extremity weakness and instability while standing. The onset of the shank pain and weakness occurred without any obvious cause. After one month, the patient experienced a shooting pain from the right shank, which traveled towards the right groin, foot and thigh. The patient had not received spinal surgery or any other spinal procedures, and did not complain of lower extremity numbness or urinary incontinence. The physical examinations revealed that there were no motor or sensory deficits in either extremity, and no palpable midline spinal displacement. Upon neurological examination, the patient demonstrated normal physical reflexes and the pathological examinations revealed no cutaneous abnormalities or dermal sinus tracts. In addition, the routine laboratory examinations were normal.

The magnetic resonance imaging (MRI) results revealed a lobulated, intradural, heterogeneous, $6.0 \times 1.5 \times 1.7-\mathrm{cm}$ mass between T12 and L2 levels of the lumbosacral spine (Fig. 1). The lesion was located in the middle of the spinal canal and extruded the spinal cord, and could not be separated from the conus medullaris. No centrum erosion or other abnormalities were identified.

The patient underwent a total resection of the tumor by means of a T12-L1 laminectomy performed under a surgical microscope. Through an incision into the dura, three connected cystic tumors were observed. A portion of the mass was in contact with the medullary and conus medullaries, and a yellow, oval-shaped, fatty cyst extruded to the cauda equina where it had become inseparable. Following the incision into the tumor cyst wall located in the conus medullaris, a white fluid containing hair follicles and gray soft tumor tissue was observed. A histopathological examination of the excised mass revealed the presence of elements from multiple germ cell layers. Under a light microscope, numerous fatty cysts consisting of neuroepithelial and epithelial tissues were observed (Fig. 2). The final histopathological diagnosis was that of a mature cystic teratoma.

The prognosis of the patient, following surgery, was good. No further neurological deterioration was observed during the three-month follow-up period and the leg pain symptoms were relieved subsequent to the surgery. 

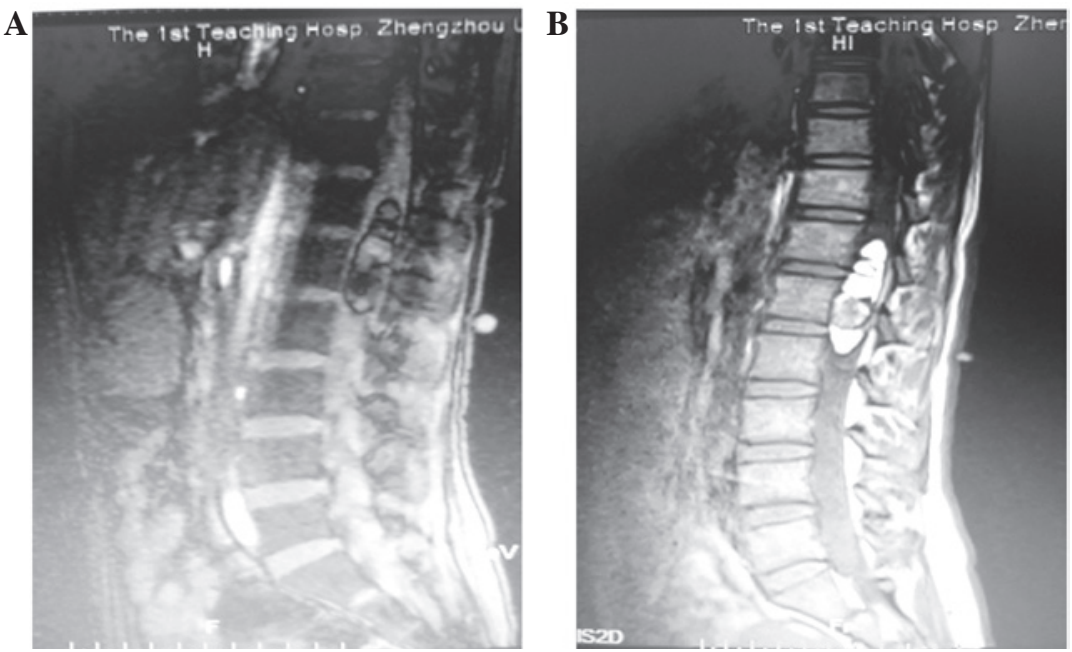

Figure 1. Axial magnetic resonance imaging (MRI) scans of the lesion. (A) Sigittal T1-weighted MRI contrast enhanced scan revealing an intramedullary mass located between T12 and L2 spinal cord levels. (B) Sigittal T2-weighted MRI image revealing a hyperintense, well-delineated intramedullary mass.
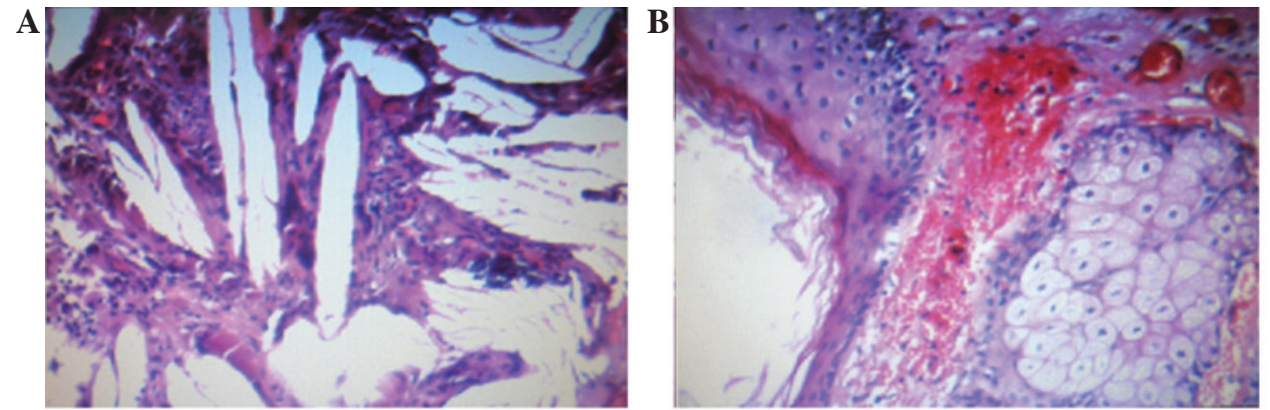

Figure 2. Histology of the excised mass. (A) Tumor consisting of stratified squamous epithelium, smooth muscle cells and adipose tissue (staining, hematoxylin and eosin; magnification, x100). (B) Glial tissue cells and smooth muscle cells (staining, hematoxylin and eosin; magnification, x200).

\section{Discussion}

Mature teratomas are a type of benign germ cell tumor, rarely observed in adult patients. The literature concerning adult intradural mature teratoma was reviewed from 1928 to the present date (14-25), and the relevant data from these cases are summarized in Table I.

The incidence of mature intraspinal teratomas in adults is rare, however, certain common features may be noted. Adult patients with mature intraspinal teratomas typically present with a delitescent onset. The literature revealed that, unlike in infants and children, intraspinal mature teratomas in adult patients were rarely observed with vertebral body anomalies or thoracolumbar spinal bifida (14,20,26-29). The main symptom endured by the adult patients included a numbness or weakness of the lower-extremities, occasionally accompanied by pain. Although the adult intraspinal teratoma patients commonly experienced a certain extent of neurological disorder, a decline of motor grade was not obvious $(14,15,20,24-26,28,29)$. Compared with in the infants and children, the lesions in the adult patients were more localized. The tumors were predominantly located between the lower thoracic vertebrae and the conus medullaris level $(30,31)$. The MRI images of the tumors were usually used as diagnostic evidence of an intraspinal mature teratoma. The morphological presentation varied in the MRI scans according to the location of the tumors. Intradural teratomas were commonly oval or lobulated heterogenous masses, whereas extradural teratomas were more commonly observed to be dumbbell-shaped. Cases of extradural teratoma are commonly accompanied with vertebral body misformation, while adult intradural teratomas are typically located beneath the dura, rarely invading the dura or vertebral body. The performance of a histopathological examination subsequent to surgery is the final analysis required to confirm the diagnosis of an intraspinal mature teratoma (10). Using light microscopy, histopathological slides of adult mature teratoma sections demonstrate multiple germinal tissue layers. The analysis of the literature revealed that in a number of cases, only two of the three germinal layers were observable; this may have been due to the fact that the derivatives of one or two of the layers had grown over the others $(9,16)$. Several tumor markers, including serum $\beta$-human chorionic gonadotropin ( $\beta$-hCG) and $\alpha$-fetoprotien (AFP), were applied for the diagnosis and prognosis of recurrences of sacrococcygeal teratoma; however, this application was limited in the mature teratomas as the recurrence may have originated from non-secreting parts of the previous lesion (32).

There are two dominant theories regarding the origin of intraspinal teratomas. The first is the dysembryogenic theory, 
Table I. Review of adult intradural teratoma cases reported in the literature, from 1928 to the present day.

\begin{tabular}{|c|c|c|c|c|c|c|}
\hline First author/s, year & No. of cases & Gender & Mean age (years) & Location & Associate abnormal & Resection \\
\hline Kubie and Fulton, 1928 & 1 & $\mathrm{~F}$ & 27.0 & $\mathrm{C} 3-\mathrm{C} 4$ & Absent & Incomplete \\
\hline Hosoi, 1931 & 1 & M & 24.0 & L2-L3 & L5-S1 spina bifida & Incomplete \\
\hline Sullivan, 1948 & 1 & $\mathrm{~F}$ & 32.0 & L1-L3 & Absent & Complete \\
\hline Bakay, 1956 & 1 & $\mathrm{~F}$ & 65.0 & L1-L2 & $\begin{array}{l}\text { L1\&L2 vertebral body } \\
\text { fusion body fusion }\end{array}$ & Incomplete \\
\hline Sloof et al, 1964 & 1 & M & 20.0 & L1 & Absent & Complete \\
\hline Rewcastle and Francoeur, 1964 & 1 & $\mathrm{~F}$ & 34.0 & $\mathrm{~T} 10$ & Absent & Incomplete \\
\hline Hansebout and Betrand, 1965 & 1 & M & 47.0 & L1-L3 & Absent & Complete \\
\hline Enestom and Von Essen, 1977 & 1 & M & 36.0 & T11-L1 & Absent & Incomplete \\
\hline Rosenbaum et al, 1978 & 1 & M & 49.0 & T9 & Absent & Complete \\
\hline Garrison and Kasdon, 1980 & 1 & M & 23.0 & $\mathrm{~L} 2$ & Absent & Complete \\
\hline Padovani et al, 1983 & 1 & $\mathrm{~F}$ & 33.0 & T12-L1 & Absent & Complete \\
\hline Pelissou-Guyotat et al, 1988 & 1 & M & 33.0 & $\mathrm{~L} 4$ & L4 spina bifida occulta & Complete \\
\hline Nicoletti et al, 1994 & 1 & M & 47.0 & Conus medullaris & $\begin{array}{l}\text { Conus medullaris } \\
\text { caudal exophy }\end{array}$ & Incomplete \\
\hline Caruso et al, 1996 & 1 & M & 41.0 & Conus medullaris & Absent & Complete \\
\hline Al-Sarraj et al, 1998 & 1 & M & 35.0 & Conus medullaris & Absent & Incomplete \\
\hline Poeze et al, 1999 & 1 & M & 23.0 & T12-L1 & Absent & Incomplete \\
\hline Fan et al, 2001 & 1 & $\mathrm{~F}$ & 43.0 & $\mathrm{~L} 2$ & Absent & Complete \\
\hline Nonomura et al, 2002 & 2 & $1 \mathrm{~F}, 1 \mathrm{M}$ & 44.5 & 1T12-L1, 2T12-L2 & Absent & Incomplete \\
\hline Hejazi and Witzmann, 2003 & 2 & $1 \mathrm{~F}, 1 \mathrm{M}$ & 32.5 & 1T11-L3, 2 L2-L4 & Absent & Complete \\
\hline Fernandez-Cornejo et al, 2004 & 1 & M & 43.0 & L1-L2 & Absent & Complete \\
\hline Ak et al, 2006 & 1 & $\mathrm{~F}$ & 43.0 & $\mathrm{C} 2-\mathrm{C} 3$ & $\begin{array}{l}\text { C3 spina bifida, } \\
\text { C5 level nodule }\end{array}$ & Complete \\
\hline Makary et al, 2007 & 1 & $\mathrm{~F}$ & 46.0 & $\mathrm{C} 1-\mathrm{C} 2$ & $\begin{array}{l}\text { C1-C2 dysraphic congenital } \\
\text { spinal malformations }\end{array}$ & Complete \\
\hline Biswas et al, 2009 & 1 & M & 28.0 & L2-L4 & Absent & Complete \\
\hline Ghostine et al, 2009 & 1 & $\mathrm{~F}$ & 65.0 & $\mathrm{C} 1-\mathrm{C} 2$ & Absent & Incomplete \\
\hline Ijiri-Kosei et al, 2009 & 1 & $\mathrm{~F}$ & 68.0 & L1-L2 & Absent & Complete \\
\hline Present case & 1 & $\mathrm{~F}$ & 22.0 & T12-L2 & Absent & Complete \\
\hline
\end{tabular}

M, male; F, female; C, cervical; T, thoracic; L, lumbar.

and the second is the misplaced germ cell theory $(33,34)$. The dysembryogenic theory indicates that spinal teratomas arise from pluripotent cells, and that in a locally disturbed developmental environment, these pluripotent cells differentiate chaotically. When such disordered development occurs in a primitive streak or a caudal cell mass, a spinal teratoma forms $(21,35)$. The misplaced germ cell theory suggests that certain pluripotent primodial germ cells of the neural tube are misplaced during migration from the yolk sac to the gonad, thus resulting in spinal teratoma formation (34).

There is evidence to support the rationale of each theory. To the best of our knowledge, dysraphic malformations are considered to support the dysembryogenic theory. The tridermal anomaly is the primary event of the disordered development of pluripotent cells in the spine, which is likely to further affect the spinal closure (21). Occurrence of a neurenteric cyst without dysraphism also supports the dysembryogenic theory (36). The explanation of isolated teratomas that are considered to have arisen by this theory is frequently questioned. The most common location for a spinal teratoma is between the lower thoracic vertebrae and the conus medullaris, which is adjacent to the caudal cell mass. This supports the theory that teratomas originate from the stochastic misplacement of a pluripotent germ cell from the caudal cell mass (30). As the caudal cell mass originates from Hensen's node, the possibility that teratomas may arise from the chaotic differentiation of pluripotent cells in Hensen's node during caudal elongation is also a plausible theory. One study that isolated three stem cell lines from sacrococcygeal teratomas also suggested that a caudal cell mass was the likely origin of teratomas (37).

In adult intraspinal teratomas, which rarely present with significant dysraphism, the misplaced germ cell theory is likely to be more feasible $(10,31,33,38,39)$. Studies focusing on 22 cases of germ cell tumors located in the spinal cord support this modified theory (40-42). In addition, the presence of ectopic primordial germ cells in the caudal cell mass has also suggested that intraspinal teratoma may result from misplaced germ cells (43). According to this theory, the disruption of the developmental field and dysraphism may be explained by the growth of the teratoma (44).

The primary treatment for teratomas is surgery, which may also be applied to mature intraspinal teratomas. An epidemiological study of spinal teratomas revealed that the recurrence rates for complete and gross resection were extremely similar (9 and $11 \%$, respectively) (32), and that the nature of mature teratomas was relatively benign. Therefore, the dominant guide for intraspinal teratoma surgery did not 
recommend radical resection $(9,10,45)$. In a study of teratomatous cysts of the spinal canal, the wall of the cyst was in intimate contact with the adjacent neural tissue in almost half of cases. This would render radical resection more difficult and affect the patient's prognosis (16). In the present case, complete resection was achieved without the injury to adjacent neural tissues, and thus, no further neurological defects were observed following the surgery. The determination of whether the residual remnants of a lesion may regrow to form a new tumor requires long-term follow-up. Due to the extremely low incidence of adult mature spinal teratoma and the limited knowledge of the disease, adjuvant therapy for such teratomas remains controversial (32). It is commonly accepted that post-operative adjuvant therapy ought to depend on the pathological examination. The application of radiotherapy is justified when malignant histological features or germ cell elements have been confirmed. Following surgery, patients should be followed up with serial MRI examinations and the potential side-effects of any radiotherapy should be considered (31). The efficacy of chemotherapy as a treatment for this disease has not been demonstrated (32).

Mature intradural teratomas in adults are rare, with few accompanying spinal anomalies. The currently preferred theory of origin of the disease is the misplaced germ cell theory. A resection of the tumor is the primary treatment methodology for adult patients, as the nature of the tumor is relatively benign and the recurrence ratio is low, even following gross resection. However, radiosurgery is not recommended.

\section{Acknowledgements}

This study was supported by the Program for New Century Excellent Talents in University (grant no. NECT-06-0611), the Three Key Disciplines Construction Project of Zhengzhou University 211 Project and the Henan Province Medical Technological Innovation Project (grant no. 2005018).

\section{References}

1. Willis RA (ed): Teratomas. In: Atlas of Tumour Pathology. 1st edition. Armed Forces Institute of Pathology, Washington, District of Columbia, pp9-58, 1951.

2. Rasmussen TB, Kernohan JW and Adson AW: Pathologic classification, with surgical consideration, of intraspinal tumors. Ann Surg 111: 513-530, 1940.

3. DeSousa AL, Kalsbeck JE, Mealey J Jr, Campbell RL and Hockey A: Intraspinal tumors in children. A review of 81 cases. J Neurosurg 51: 437-445, 1979.

4. Matson DD and Tachdjian MO: Intraspinal tumors in infants and children; review of 115 cases. Postgrad Med 34: 279-285, 1963.

5. Baysefer A, Akay KM, Izci Y, Kayali H and Timurkaynak E: The clinical and surgical aspects of spinal tumors in children. Pediatr Neurol 31: 261-266, 2004

6. Garrison JE and Kasdon DL: Intramedullary spinal teratoma: case report and review of the literature. Neurosurgery 7: 509-512, 1980

7. Huang JC, Shin JS, Huang YT, et al: Primary retroperitoneal teratoma in an adult. J Chin Med Assoc 66: 497-500, 2003.

8. Monajati A, Spitzer RM, Wiley JL and Heggeness L: MR imaging of a spinal teratoma. J Comput Assist Tomogr 10: 307-310, 1986

9. Nonomura Y, Miyamoto K, Wada E, et al: Intramedullary teratoma of the spine: report of two adult cases. Spinal Cord 40 : 40-43, 2002.

10. Sharma MC, Aggarwal M, Ralte AM, et al: Clinicopathological study of spinal teratomas. A series of 10 case. J Neurosurg Sci 47 95-100; discussion 100, 2003.
11. Smoker WR, Biller J, Moore SA, Beck DW and Hart MN: Intradural spinal teratoma: case report and review of the literature. AJNR Am J Neuroradiol 7: 905-910, 1986.

12. Krishna KK, Agarwal PA, Agarwal SI and Jain MM: Dermoid of the conus medullaris. J Clin Neurosci 11: 796-797, 2004.

13. Chandler CL, Uttley D, Wilkins PR and Kavanagh TG: Primary spinal malignant schwannoma. Br J Neurosurg 8: 341-345, 1994.

14. Banna $\mathrm{M}$ and Talalla A: Intraspinal dermoids in adults. Br J Radiol 48: 28-30, 1975

15. Kumar S, Gulati DR and Mann KS: Intraspinal dermoids. Neurochirurgia (Stuttg) 20: 105-108, 1977.

16. Rosenbaum TJ, Soule EH and Onofrio BM: Teratomatous cyst of the spinal canal. Case report. J Neurosurg 49: 292-297, 1978.

17. Goodrich A, Wolf CR and Allen MB Jr: Intradural dermoid cyst. A case report. Spine (Phila Pa 1976) 9: 832-834, 1984.

18. Awwad EE, Backer R and Archer CR: The imaging of an intraspinal cervical dermoid tumor by MR, CT, and sonography. Comput Radiol 11: 169-173, 1987.

19. Shikata J, Yamamuro T, Mikawa Y and Kotoura Y: Intraspinal epidermoid and dermoid cysts. Surgical results of seven cases. Arch Orthop Trauma Surg 107: 105-109, 1988.

20. Sun J, Bao X and Sun W: Intramedullary spinal teratoma. Zhonghua Wai Ke Za Zhi 34: 732-734, 1996 (In Chinese).

21. Koen JL, McLendon RE and George TM: Intradural spinal teratoma: evidence for a dysembryogenic origin. Report of four cases. J Neurosurg 89: 844-851, 1998.

22. Kondo M, Hokezu Y, Yanai S, Nagamatsu K and Kida H: A case of thoracic extradural spinal cord teratoma with neurological sequelae more than 10 years after surgery. Rinsho Shinkeigaku 38: 693-696, 1998 (In Japanese).

23. Stevens QE, Kattner KA, Chen YH and Rahman MA: Intradural extramedullary mature cystic teratoma: not only a childhood disease. J Spinal Disord Tech 19: 213-216, 2006.

24. Sung KS, Sung SK, Choi HJ and Song YJ: Spinal intradural extramedullary mature cystic teratoma in an adult. J Korean Neurosurg Soc 44: 334-337, 2008.

25. Bouaziz M, Haouam K, Laouar O and Lankar A: A case of cervical intradural extramedullary mature cystic teratoma: diagnosis and management. Neurochirurgie 57: 88-91, 2011 (In French).

26. Kwinta B, Adamek D, Moskala M and Stachura K: Tumours and tumour-like lesions of the spinal canal and spine. A review of 185 consecutive cases with more detailed close-up on some chosen pathologies. Pol J Pathol 62: 50-59, 2011.

27. Bloomer CW, Ackerman A and Bhatia RG: Imaging for spine tumors and new applications. Top Magn Reson Imaging 17: 69-87, 2006.

28. Wilkinson N, Reid H and Hughes D: Intradural bronchogenic cysts. J Clin Pathol 45: 1032-1033, 1992.

29. Reddy DR, Prabhakar V and Rao BD: Intraspinal teratoma. Neurol India 19: 45-47, 1971.

30. Park SC, Kim KJ, Wang KC, Choe G and Kim HJ: Spinal epidural teratoma: review of spinal teratoma with consideration on the pathogenesis: case report. Neurosurgery 67: E1818-E1825, 2010.

31. Ak H, Ulu MO, Sar M, Albayram S, Aydin S and Uzan M: Adult intramedullary mature teratoma of the spinal cord: review of the literature illustrated with an unusual example. Acta Neurochir (Wien) 148: 663-669; discussion 669, 2006.

32. Allsopp G, Sgouros S, Barber P and Walsh AR: Spinal teratoma: is there a place for adjuvant treatment? Two cases and a review of the literature. Br J Neurosurg 14: 482-488, 2000.

33. al-Sarraj ST, Parmar D, Dean AF, Phookun G and Bridges LR: Clinicopathological study of seven cases of spinal cord teratoma: a possible germ cell origin. Histopathology 32: 51-56, 1998.

34. Rewcastle NB and Francoeur J: Teratomatous cysts of the spinal canal; with "sex chromatin” studies. Arch Neurol 11: 91-99, 1964.

35. Reddy CR, Rao KV and Jagabhandhu N: Intraspinal teratoma associated with diastematomyelia. Indian J Pathol Bacteriol 11: 77-81, 1968.

36. Paleologos TS, Thom M and Thomas DG: Spinal neurenteric cysts without associated malformations. Are they the same as those presenting in spinal dysraphism? Br J Neurosurg 14: 185-194, 2000

37. Busch C, Bareiss PM, Sinnberg T, et al: Isolation of three stem cell lines from human sacrococcygeal teratomas. J Pathol 217: 589-596, 2009

38. Jian W, Ying W and Chao Y: Intramedullary spinal teratoma of the conus medullaris: report of two cases. Acta Neurochir (Wien) 152: $553-554,2010$. 
39. Sharma MC, Jain D, Sarkar C, et al: Spinal teratomas: a clinico-pathological study of 27 patients. Acta Neurochir (Wien) 151: 245-252; discussion 252, 2009.

40. Biswas A, Puri T, Goyal S, et al: Spinal intradural primary germ cell tumour - review of literature and case report (Review). Acta Neurochir (Wien) 151: 277-284, 2009.

41. Takahashi M, Koyama H, Matsubara T, Murata H, Miura K and Nagano A: Mixed germinoma and choriocarcinoma in the intramedullary spinal cord: case report and review of the literature. J eurooncol 76: 71-75, 2006.

42. Kurisaka M, Moriki A, Mori K and Sonobe H: Primary yolk sac tumor in the spinal cord. Childs Nerv Syst 14: 653-657, 1998.

43. Runyan C, Gu Y, Shoemaker A, Looijenga L and Wylie C: The distribution and behavior of extragonadal primordial germ cells in Bax mutant mice suggest a novel origin for sacrococcygeal germ cell tumors. Int J Dev Biol 52: 333-344, 2008.

44. Dias MS and Walker ML: The embryogenesis of complex dysraphic malformations: a disorder of gastrulation? Pediatr Neurosurg 18: 229-253, 1992.

45. Hejazi N and Witzmann A: Spinal intramedullary teratoma with exophytic components: report of two cases and review of the literature. Neurosurg Rev 26: 113-116, 2003.

46. Kubie LS and Fulton JF: A clinical and pathological study of two teratomatous cysts of the spinal cord, containing mucous and ciliated cells. Surg Gynec Obstet 47: 297-311, 1928.

47. Hosoi K: Multiple neurofibromatosis disease. Arch Surg 22 258-281, 1931

48. Sullivan BH: Intraspinal teratoma, with report of a case. Brooklyn Hosp J 6: 142-145, 1948.

49. Bakay L: Case reports of the massachusetts general hospital weekly clinicopathological exercises: case 42502. N Engl J Med 255: 1153-1157, 1956.

50. Sloof JL, Kernohan JW and McCarty CS: Primary Intramedullary Tumors of the Spinal Cord and Filum Terminale. WB Saunders, Philadelphia, PA, pp134, 1964.
51. Hansebout RR and Bertrand G: Intraspinal teratoma simulating protruded intervertebral disc. J Neurosurg 22: 374-379, 1965

52. Eneström S and von Essen C: Spinal teratoma. Acta Neurochir (Wien) 39: 121-126, 1977.

53. Padovani R, Tognetti F, Laudadio S, et al: Teratoid cyst of the spinal cord. Neurosurgery 13: 74-77, 1983.

54. Pelissou-Guyotat I, Sindou M, Pialat J, et al: Apropos of a surgically treated case. Review of the literature. Neurochirurgie 34: 205-209, 1988 (Article in French).

55. Nicoletti GF, Passanisi M, Platania N, et al: Intramedullary spinal cystic teratoma of the conus medullaris with caudal exophytic development: case report. Surg Neurol 41: 106-111, 1994.

56. Caruso R, Antonelli M, Cervoni L, et al: Intramedullary teratoma: case report and review of the literature. Tumori 82 : 616-620, 1996

57. Poeze M, Herpers MJ, Tjandra B, et al: Intramedullary spinal teratoma presenting with urinary retention: case report and review of the literature. Neurosurgery 45: 379-385, 1999.

58. Fan X, Turner JE, Turner TM, et al: Carcinoid tumor development in an intramedullary spinal cord mature teratoma. AJNR Am J Neuroradiol 22: 1778-1781, 2001.

59. Fernández-Cornejo VJ, Martínez-Pérez M, Polo-García LA, et al: Cystic mature teratoma of the filum terminale in an adult. Case report and review of the literature. Neurocirugía (Astur) 15: 290-293, 2004.

60. Makary R, Wolfson D, Dasilva V, et al: Intramedullary mature teratoma of the cervical spinal cord at C1-2 associated with occult spinal dysraphism in an adult. Case report and review of the literature. J Neurosurg Spine 6: 579-584, 2007.

61. Ghostine S, Perry E, Vaynman S, et al: The rare case of an intramedullary cervical spinal cord teratoma in an elderly adult: case report and literature review. Spine (Phila Pa 1976) 34: E973-E978, 2009.

62. Ijiri K, Hida K, Yano S, et al: Huge intradural ossification caused by a mature spinal teratoma: case report. Neurosurgery 64 E1200-E1201; discussion E1201, 2009. 